\title{
PENGARUH KREATIVITAS DAN INOVASI TERHADAP KEUNGGULAN BERSAING (STUDI KASUS WEDDING ORGANIZER HASTINA PUSPITA DECORATION KOTA JAMBI)
}

\author{
Adhe Ira Riany ${ }^{1)}$, Dahmiri ${ }^{2)}$ \\ ${ }^{1,2)}$ Prodi Manajemen FEB Universitas Jambi \\ dahmiri@unja.ac.id
}

\begin{abstract}
Abstrak
Penelitian ini bertujuan untuk mengetahui pengaruh kreativitas dan inovasi terhadap keunggulan bersaing (studi kasus wedding organizer Hastina Puspita Decoration Jambi). Populasi dalam penelitian ini adalah konsumen yang pernah memakai jasa wedding organizer Hastina Puspita decoration pada tahun 2019, jumlah sampel dihitung berdasarkan rumus Slovin yakni sebanyak 70 responden. Pengumpulan sampel dilakukan dengan menyebarkan kuesioner dengan teknik Simple random sampling. Metode analisis data menggunakan metode deskriptif dan metode kuantitatif yaitu analisis regresi linier berganda dengan tingkat signifikan 0,05. Keseluruhan analisis dihitung menggunakan program SPSS versi 24. Hasil dari penelitian menunjukkan, bahwa (1) kreativitas dan inovasi berpengaruh positif dan signifikan terhadap keunggulan bersaing pada wedding organizer Hastina Puspita Dcoration Jambi. (2) inovasi memiliki pengaruh yang paling dominan terhadap keunggulan bersaing wedding organizer Hastina Puspita Decoration Jambi.
\end{abstract}

Kata Kunci : Kreativitas, Inovasi dan Keunggulan Bersaing

\begin{abstract}
This study aims to determine the effect of creativity and innovation on competitive advantage (a case study of wedding organizer Hastina Puspita Decoration Jambi). The population in this study were consumers who have used the services of wedding organizer Hastina Puspita Decoration Jambi in 2019, the number of samples was calculated based on the formula Slovin that as many as 70 respondents. Sample collection is done by distributing questionnaires with Simple random sampling technique. The method of data analysis uses descriptive methods and quantitative methods, namely multiple linear regression analysis with a significant level of 0.05. The overall analysis was calculated using the SPSS version 24 program. The results of the study show that (1) creativity and innovation have a positive and significant effect on competitive advantage on wedding organizer Hastina Puspita Decoratin Jambi. (2) innovation has the most dominant influence on competitive advantage wedding organizer Hastina Puspita Decoration Jambi.
\end{abstract}

Keywords: Creativity, Innovation and Competitive Advantage

\section{PENDAHULUAN}

Dunia bisnis adalah sebuah kegiatan wirausaha yang penuh dengan tantangan. Karena itu di perlukan sikap disiplin, fokus, serta kreatifitas yang harus dimiliki para wirausaha. Mampu melihat peluang serta berani mengambil resiko juga merupakan hal yang penting untuk para wirausaha tetap berada pada pasarnya. Banyaknya jumlah pengangguran di Indonesia merupakan hambatan yang besar dalam memajukan perekonomian Indonesia. Selain itu lapangan kerja yang tersedia juga masih minim. 
Seorang wirausaha tidak mudah menciptakan suatu usaha dengan waktu yang singkat. Ide usaha yang menarik, mampu melihat peluang, dan siap akan resiko yang ada adalah bekal yang diperlukan wirausaha untuk siap bersaing di pasar. Wirausaha harus mempunyai skill tertentu, pengetahuan mengolah dengan cara yang berbeda, serta mampu membuat produk yang kreatif dan inovatif untuk siap masuk ke pasar dan bersaing.

Dapat dilihat bahwa kreatifitas adalah hal yang sangat penting bagi wirausahawan. Menurut Zimmerer \& Scarborough (2004) kreativitas adalah kemampuan untuk menghasilkan ide baru, dengan mengkombinasikan, dan mengubah ide yang sudah ada kemudian diproses melalui beberapa tanggapan sehingga menghasilkan produk atau jasa yang kreatif. Suatu perusahaan dikatakan berkembang jika perusahaan tersebut mempunyai sumber daya-sumber daya yang baik. Didukung juga dengan kreativitas yang tinggi perusahaan juga akan berani menghadapi pasar yang berubah-ubah. Setiap perusahan dituntut untuk melakukan kreativitas terhadap produk yang mereka pasarkan.

Kreativitas produk memiliki kemampuan untuk mengembangkan dan menggabungkan ide baru dari ide yang telah dimilikinya yang bersumber dari pihak pelanggan sehingga membentuk kreativitas produk yang dapat memberi pengaruh terhadap keunggulan bersaing.

Tak hanya kreatifitas, inovasi juga sangat diperlukan dalam perkembangan perusahaan. Inovasi memiliki fungsi yang khas bagi wirausahaan. Dengan inovasi wirausahawan menciptakan baik sumber daya produksi baru maupun pengelolaan sumber daya yang ada dengan peningkatan nilai potensi untuk menciptakan sesuatu yang tidak ada menjadi ada. Dengan demikian inovasi adalah suatu kombinasi visi untuk menciptakan suatu gagasan yang lebih baik dan keteguhan serta dedikasi untuk mempertahankan konsep melalui implementasi. Hills (2008) mendefinisikan inovasi sebagai ide, praktek atau obyek yang dianggap baru oleh seseorang individu atau unit pengguna lainnya. Perusahaan dapat melakukan berbagai inovasi dengan membuat berbagai macam desain produk dan menambah nilai guna suatu barang.

Inovasi sangat penting bagi sebuah perusahaan. Inovasi produk juga merupakan salah satu dampak dari perubahan teknologi yang cepat. Kemajuan teknologi yang cepat dan tingginya tingkat persaingan menuntut setiap perusahaan untuk terus menerus melakukan inovasi yang pada akhirnya akan meningkatkan keunggulan pada perusahaan tersebut.

Dengan semakin berkembangnya suatu bidang usaha pasti akan banyak usaha sejenis yang bermunculan, hal ini juga terjadi pada usaha jasa wedding organizer yang mengakibatkan adanya persaingan bisnis yang semakin kompetitif. Dalam persaingan yang semakin ketat perusahaan harus memiliki daya saing yang cukup kuat untuk dapat terus bersaing dengan perusahaan lainnya terutama perusahaan sejenis. Setiap perusahaan pasti memiliki strategi yang berbeda dalam mencapai keunggulan bersaing. Keunggulan bersaing adalah kemampuan suatu badan usaha untuk memberikan nilai lebih terhadap produknya dibandingkan para pesaingnya dan nilai tersebut memang mendatangkan manfaat bagi pelanggan (Stygraha, 1994).

Keunggulan bersaing menurut Porter (1998) adalah kemampuan suatu perusahaan untuk meraih keuntungan ekonomis di atas laba yang mampu diraih oleh pesaing di pasar dalam industri yang sama. Berdasarkan studi yang dilakukan oleh Porter, beberapa cara untuk memperoleh keunggulan bersaing antara lain dengan menawarkan produk atau jasa dengan harga minimum (cost leadership), menawarkan produk atau jasa dengan yang memiliki keunikan dibanding pesaingnya (differentiation), dengan 
memfokuskan diri pada segmen tertentu (focus). Keunggulan bersaing menjadi kunci pokok untuk tetap bertahan dalam era global.

Wedding Organizer merupakan Event Organizer yang menawarkan berbagai macam paket pernikahan yang bisa dipilih diantaranya catering service, tata rias dan busana, florist dan dekorasi, gedung, dekorasi pelaminan, photography dan video shooting, MC dan hiburan yang dibutuhkan untuk mengisi sebuah acara. Bukan hanya acara pernikahan saja, namun bisa juga seperti khitanan, tasyakuran dan lain-lain.

Jasa wedding organizer memiliki peluang yang sangat menjanjikan, Karena memiliki daya tarik sendiri bagi masyarakat, dan sasaran yang ditujukan dari berbisnis wedding organizer sangatlah tepat. Di Indonesia pada tahun 2018, penduduk yang telah menikah sebanyak $60,00 \%$ untuk wanita, dan 58,97\% untuk pria. Sedangkan di Jambi sendiri jumlah pasangan yang menikah sebanyak $60,68 \%$ (bps.go.id).

Hastina Puspita Decoration adalah suatu perusahaan yang bergerak dibidang jasa pelayanan, seperti Event Organizer (EO), Wedding Organizer (WO), dan Make Up Artist. Wedding Organizer pada Hastina Puspita Decoration melayani dalam jasa paket pernikahan. Adapun paket yang ditawarkan antara lain

Tabel 1.1. Daftar harga paket Wedding Organizer Hastina Puspita DecorationKota Jambi

\begin{tabular}{|c|l|c|}
\hline No & \multicolumn{1}{|c|}{ Nama Paket } & Harga \\
\hline 1. & Silver Package & Rp. 18.000 .000 \\
\hline 2. & Gold Package I & Rp. 20.000 .000 \\
\hline 3. & Gold Package II & Rp. 30.000 .000 \\
\hline 4. & Platinum Package I & Rp. 35.000 .000 \\
\hline 5. & Platinum Package II & Rp. 50.000 .000 \\
\hline
\end{tabular}

Sumber : Hastina puspita Decoration

Dilihat dari tabel paket yang ditawarkan oleh Hastina Puspita Decoration, terlihat beberapa perbedaan dari setiap paket yang dapat dilihat dari harganya. Tentu dalam setiap paket mempunyai keuntungan masing-masing dari setiap produk maupun jasa yang ditawarkan.

Hastina Puspita Decoration merupakan salah satu Wedding Organizer yang besar, maju dan sudah terkenal di Provinsi Jambi tepatnya di Tambak Sari, sebelah Taman PKK Kota Jambi. Dengan berbagai kreativitas dan inovasi yang diciptakan, mereka mampu menarik perhatian konsumen khususnya bagi calon- calon pengantin yang akan membuat resepsi acara mereka.

Berdasarkan latar belakang tersebut, penulis ingin meneliti perihal seberapa besar pengaruh kreativitas dan inovasi terhadap keunggulan bersaing wedding organizer Hastina Puspita Decoration Jambi. Studi mengenai pengaruh kreativitas dan inovasi terhadap keunggulan bersaing ini diharapkan menjadi bahan acuan pembelajaran bagi generasi yang akan datang.

\section{Tujuan Penelitian}

1. Untuk mengetahui pengaruh kreativitas dan inovasi produk secara simultan terhadap keunggulan bersaing usaha Wedding Organizer Hastina Puspita Decoration Kota Jambi.

2. Untuk mengetahui pengaruh kreativitas dan inovasi produk secara simultan terhadap keunggulan bersaing usaha Wedding Organizer Hastina Puspita Decoration Kota Jambi. 
3. Untuk mengetahui variabel mana yang berpengaruh dominan terhadap keunggulan bersaing usaha Wedding Organizer Hastina Puspita Decoration Kota Jambi.

\section{TINJAUAN PUSTAKA}

\section{Kewirausahan}

Menurut Hendro (2011:29) kewirausahaan adalah padanan kata darientrepreneurship dalam bahasa Inggris, unternehmer dalam bahasa Jerman, ondernemen dalam bahasa Belanda. Kata entrepreneur berasal dari bahasa Prancis, yaitu entreprende yang berarti petualang, pengambil resiko, kontraktor, pengusaha (orang yang mengusahakan suatu pekerjaan tertentu), dan pencipta yang menjual hasil ciptaannya.

\section{Kreativitas}

Pengertian kreativitas menurut Supriadi (2015) merupakan "kemampuan seseorang untuk melahirkan sesuatu yang baru, baik berupa gagasan maupun karya nyata yang relative berbeda dengan apa yang telah ada".

\section{Inovasi}

Menurut Buchari (2004) inovasi berarti mengamati konsumen untuk menemukan dan memuaskan konsumennya dengan memberikan produk yang baru. Namun Kotler (2004) menambahkan bahwa inovasi tidak hanya terbatas pada pengembangan produk-produk atau jasa-jasa baru. Inovasi juga termasuk pada pemikiran bisnis baru dan proses baru.

\section{Keungulan Bersaing}

Menurut Kotler \& Armstrong (2004) Keunggulan bersaing adalah keunggulan terhadap pesaing yang diperoleh dengan menawarkan nilai lebih rendah maupun dengan memberikan manfaat lebih besar karena harganya lebih tinggi.

\section{Wedding Organizer}

Fithrati (2014) Wedding Organizer (WO) adalah "jasa pengorganisasian untuk acara pernikahan, baik dalam perencanaanya maupun pada saat hari pernikahan”.

\section{METODE PENELITIAN}

Jenis penelitian yang digunakan dalam penelitian ini adalah penelitian deskriptif dengan metode kuantitatif dengan menggunakan kuesioner sebagai pengumpulan data. Populasi dalam penelitian ini adalah konsumen yang pernah memakai jasa wedding organizer Hastina Puspita Decoration Jambi. Teknik pengambilan sampel menggunakan Simple random sampling dengan jumlah sampel sebanyak 70 orang. Teknik pengumpulan data menggunakan kuesioner yang telah diuji validitas dan reliabilitasnya. Teknik analisis data yang digunakan adalah regresi berganda.

\section{HASIL DAN PEMBAHASAN}

\section{Uji Asumsi Klasik}

Pengujian asumsi klasik digunakan untuk mengetahui model regresi linear berganda dapat digunakan atau tidak. Apabila uji ini terpenuhi maka alat uji dimaksud dapatdipergunakan untuk menguji model yang terdiri dari :

\section{Uji Normalitas}

Pada diagram pencar hasil olah data SPSS dengan dasar pengambilan keputusan 
yaknijika data menyebar disekitar garis diagonal dan mengikuti arah garis diagonal, maka modelregresi memenuhi asumsi normalitas. Hasil pengujian normalitas dapat dilihat pada Gambar 1

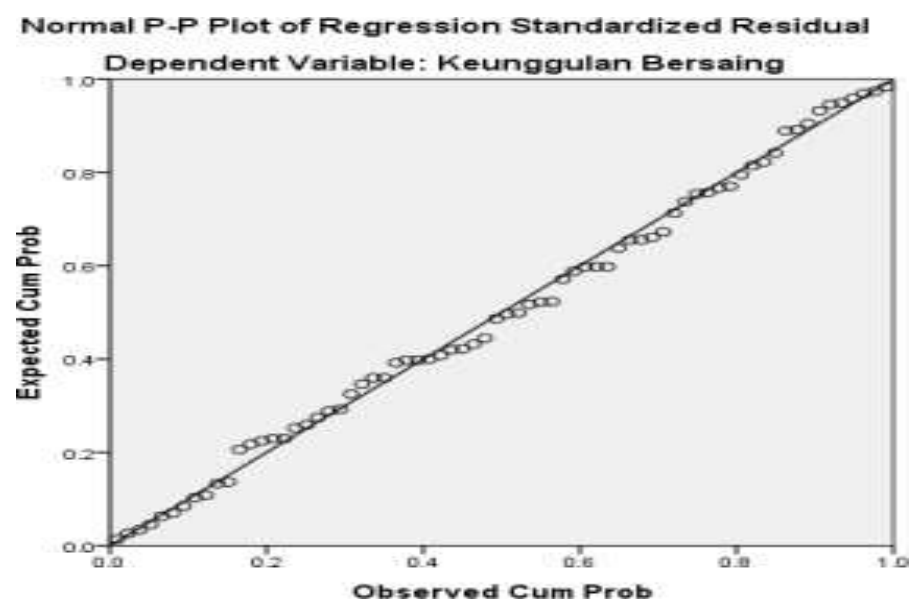

Gambar 1 Uji Normalitas

Pada grafik scatter plot terlihat titik yang mengikuti data disepanjang garis diagonal. Hal ini berarti data berdistribusi normal.

Uji Linearitas

Hasil uji liniearitas tersebut dapat dilihat pada tabel dibawah ini:

a. Variabel Kreativitas

Tabel 2.Hasil Uji Linearitas Variabel Kreativitas $\left(\mathbf{X}_{1}\right)$ ANOVA Table

\begin{tabular}{|ll|r|r|r|r|r|}
\hline & & $\begin{array}{l}\text { Sum of } \\
\text { Squares }\end{array}$ & df & $\begin{array}{l}\text { Mean } \\
\text { Square }\end{array}$ & F & Sig. \\
\hline Keunggulan Between & (Combined) & 293,410 & 13 & 22,570 & $3,561,000$ \\
\hline $\begin{array}{l}\text { Bersaing * } \\
\text { Kreativitas }\end{array}$ & Groups & Linearity & 161,798 & 1 & 161,798 & $25,528,000$ \\
\cline { 2 - 7 } & $\begin{array}{l}\text { Deviation from } \\
\text { Linearity }\end{array}$ & 131,611 & 12 & 10,968 & $1,730,085$ \\
\cline { 2 - 8 } & & 354,933 & 56 & 6,338 & & \\
\hline
\end{tabular}

Sumber: Hasil Olahan SPSS versi 24 (2020)

Berdasarkan dari tabel 2 tersebut, menandakan bahwa nilai probabilitas lebih besar dari 0,05 yaitu 0,085 $>0,05$. Sehingga dapat disimpulkan bahwa hubungan antara variabel Kreativitas $\left(\mathrm{X}_{1}\right)$ dengan Keunggulan Bersaing $(\mathrm{Y})$ adalah linear. 


\section{b. Variabel Inovasi}

Tabel 3.Hasil Uji Linearitas Variabel Inovasi $\left(\mathbf{X}_{2}\right)$

ANOVA Table

\begin{tabular}{|c|c|c|c|c|c|c|c|}
\hline & & & $\begin{array}{l}\text { Sum of } \\
\text { Squares }\end{array}$ & df & $\begin{array}{l}\text { Mean } \\
\text { quare }\end{array}$ & $\mathrm{F}$ & Sig. \\
\hline $\begin{array}{l}\text { Keunggulan } \\
\text { Bersaing* }\end{array}$ & $\begin{array}{l}\text { Between } \\
\text { Groups }\end{array}$ & (Combined) & 227,526 & 13 & 17,502 & 4,903 &, 000 \\
\hline Inovasi & & Linearity & 130,216 & 1 & 130,216 & 36,476 & , 000 \\
\hline & & $\begin{array}{l}\text { Deviation from } \\
\text { Linearity }\end{array}$ & 97,310 & 12 & 8,109 & 2,272 & ,020 \\
\hline & Within G & & 199,917 & 56 & 3,570 & & \\
\hline & Total & & 427,443 & 69 & & & \\
\hline
\end{tabular}

Sumber: Hasil Olahan SPSS versi 24 (2020)

Berdasarkan dari tabel 3 tersebut, menandakan bahwa nilai probabilitas lebih besar dari 0,05 yaitu 0,020 >0,05. Sehingga dapat disimpulkan bahwa hubungan antara variabel Inovasi $\left(\mathrm{X}_{2}\right)$ dengan Keunggulan Bersaing $(\mathrm{Y})$ adalah linear.

\section{Uji Multikolinearitas}

Tabel 4. Hasil Uji Multikolinearitas

Coefficients $^{\mathrm{a}}$

\begin{tabular}{|ll|c|}
\hline \multirow{2}{*}{ Model } & $\begin{array}{l}\text { Collinearity } \\
\text { Statistics }\end{array}$ \\
\cline { 2 - 3 } & Tolerance VIF \\
\hline 1 & (Constant) & \\
\hline & $\begin{array}{l}\text { Kreativitas } \\
(\mathrm{X} 1)\end{array}$ & $, 6401,562$ \\
\hline Inovasi (X2) & \multicolumn{2}{|c|}{$, 6401,562$} \\
\hline
\end{tabular}

a. Dependent Variable: Keunggulan Bersaing (Y)

Berdasarkan tabel di atas, maka nilai VIF $<10$ atau $1,562<10$. Dengan demikian maka Ho diterima dan Ha ditolak yang artinya semua variabel yaitu antara kreativitas $\left(\mathrm{X}_{1}\right)$ dan inovasi $\left(\mathrm{X}_{2}\right)$ tidak terjadi multikolinearitas.

\section{Uji Heterokedastisitas}

Tabel 5. Hasil Uji Heterokedastisitas

Coefficients $^{\mathrm{a}}$

\begin{tabular}{|c|c|c|c|c|c|c|}
\hline & \multirow[t]{2}{*}{ Model } & \multicolumn{2}{|c|}{$\begin{array}{l}\text { Unstandardized } \\
\text { Coefficients }\end{array}$} & $\begin{array}{l}\text { Standardized } \\
\text { Coefficients }\end{array}$ & \multirow[t]{2}{*}{$\mathrm{t}$} & \multirow[t]{2}{*}{ Sig. } \\
\hline & & $\mathrm{B}$ & Std. Error & Beta & & \\
\hline 1 & (Constant) & ,673 & 1,642 & & ,410 & 683 \\
\hline & Kreativitas (X1) & ,003 & ,066 & ,066 - r - & ,043 & ,966 \\
\hline & Inovasi (X2) & ,041 & ,181 & ,076 & ,500 & 619 \\
\hline
\end{tabular}

a. Dependent Variable: RES2 
Berdasarkan tabel di atas, nilai signifikansi variabel kreativitas lebih besar dari 0,05 atau 0,966 > 0.05. Sehingga Ho diterima atau tidak ada heterokedastisitas. Kemudian untuk variabel inovasi produk $\left(\mathrm{X}_{2}\right)$, nilai signifikansi inovasi produk lebih besar dari 0,05 atau 0,619 >0.05. Sehingga Ho diterima atau tidak ada heterokedastisitas.

\section{Uji Hipotesis}

\section{Uji f (Uji Simultan)}

Berikut merupakan hasil uji F yang di sajikan pada tabel di bawah ini :

Tebel 6 .Hasil Analisis Uji f ANOVA ${ }^{a}$

\begin{tabular}{|l|l|r|r|r|l|}
\hline Model & $\begin{array}{l}\text { Sum of } \\
\text { Squares }\end{array}$ & Df & Mean Square & F & Sig. \\
\hline $1 \quad$ Regression & 177,713 & 2 & 88,656 & 17,959 &, $000^{\mathrm{b}}$ \\
\hline Residual & 330,759 & 67 & 4,937 & & \\
\hline Total & 508,071 & 69 & & & \\
\hline
\end{tabular}

a.Dependent Variable: Keunggulan_Bersaing (Y)

b.Predictors: (Constant), Inovasi (X2), Kreativitas (X1)

Berdasarkan hasil uji F dengan bantuan perhitungan dari program SPSS 24.0, maka terlihat bahwa dalam uji $\mathrm{F}$ statistik ini terlihat bahwa nilai $\mathrm{F}_{\text {hitung }}$ lebih besar dari nilai $\mathrm{F}_{\text {tabel }}$ yaitu 17,959 > 3,13. Untuk mengetahui pengaruh antar variabel secara simultan juga dapat dilihat dari nilai signifikansinya. Seperti yang terlihat pada tabel bahwa nilai signifikansinya kurang dari 0,05 yaitu $0,000<0,05$. Sehingga dapat disimpulkan bahwa variabel kreativitas dan inovasi secara bersama-sama mempengaruhi keunggulan bersaing.

\section{Uji t (Uji Parsial)}

Tabel 7. Hasil Uji Uji t ${ }_{\text {hitung }}$ (Uji Parsial) Coefficients ${ }^{a}$

\begin{tabular}{|c|c|c|c|c|c|c|}
\hline & \multirow[t]{2}{*}{ Model } & \multicolumn{2}{|c|}{$\begin{array}{l}\text { Unstandardized } \\
\text { Coefficients }\end{array}$} & \multirow{2}{*}{$\begin{array}{c}\text { Standardized } \\
\text { Coefficients } \\
\mathrm{r} \quad \text { Beta }\end{array}$} & \multirow[t]{2}{*}{$\mathrm{T}$} & \multirow[t]{2}{*}{ Sig. } \\
\hline & & B & Std. Error & & & \\
\hline \multirow[t]{3}{*}{1} & (Constant) & 11,545 & 2,715 & & 4,252 &, 000 \\
\hline & Kreativitas (X1) & ,233 & , 109 & ,263 & 2,136 & ,036 \\
\hline & Inovasi (X2) & ,430 & , 134 & ,394 & 3,199 & ,002 \\
\hline
\end{tabular}

a. Dependent Variable: Keunggulan Bersaing (Y)

Berdasarkan tabel 7 hasil uji parsial yang telah dilakukan, diperoleh nilai :

a. Kreativitas $\left(\mathrm{X}_{1}\right)$ terhadap Keunggulan Bersaing $(\mathrm{Y})$

Pada tabel diatas diperoleh hasil nilai thitung kreativitas sebesar 2,136 dengan signifikan 0,036. Hasil perhitungan tersebut menyatakan bahwa kreativitas berpengaruh positif dan signifikan terhadap keunggulan bersaing dengan $t_{h t u n g}>t_{\text {tabel }}(2,136>1,667)$ dan nilai signifikan yang lebih kecil dari nilai probabilitas $(0,036<0,05), \mathrm{H}_{1}$ diterima.

b. Inovasi $\left(\mathrm{X}_{2}\right)$ terhadap Keunggulan Bersaing (Y)

Pada tabel 7 diperoleh hasil nilai thitung inovasi sebesar 3,199 dengan signifikan 0,002. Hasil perhitungan tersebut menyatakan bahwa inovasi berpengaruh positif dan signifikan terhadap keunggulan bersaing dengan $t_{\text {hitung }}>t_{\text {tabe }}(3,199>1,667)$ dan nilai signifikan yang lebih kecil dari nilai probabilitas $(0,002<0,05), \mathrm{H}_{1}$ diterima. 
Pada tabel 7 maka dapat diketahui persamaan regresi yang terbentuk. Adapun persamaan regresi linear yang terbentuk adalah :

$$
Y=11,545+0,233 X_{1}+0,430 X_{2}
$$

1. Konstanta $(\mathrm{a})=11,545$

Ini berarti jika semua variabel independent (kreativitas dan inovasi) di anggap sama dengan nol (0) maka nilai variabel dependent (keunggulan bersaing) sebesar 11,545.

2. Kreativitas $\left(\mathrm{X}_{1}\right) 0,231$

Nilai koefisien kreativitas bertanda positif terhadap keungulan bersaing dengan nilai koefisien regresi sebesar 0,233. Hal ini menunjukan bahwa setiap nilai variabel kreativitas di naikan 1 point atau satuan sementara variabel kreativitas diasumsikan tetap, maka variabel keunggulan bersaing (Y) akan meningkat sebesar 0,233.

3. Inovasi $\left(\mathrm{X}_{2}\right) 0,430$

Nilai koefisien inovasi bertanda positif terhadap kepunggulan bersaing dengan nilai koefisien regresi sebesar 0,430. Hal ini menunjukan bahwa

setiap nilai variabel inovasi di naikan 1 point atau satuan sementara variabel inovasi diasumsikan tetap, maka variabel keunggulan bersaing (Y) akan meningkat sebesar 0,430.

\section{Koefisien Determinan $\left(\mathbf{R}^{2}\right)$}

Tebel 8. Hasil Uji Koefisien Determinan $\left(\mathbf{R}^{2}\right)$ Model Summary

\begin{tabular}{|l|l|l|l|l|}
\hline Model & R & R Square & $\begin{array}{c}\text { Adjusted R } \\
\text { Square }\end{array}$ & $\begin{array}{c}\text { Std. Error of } \\
\text { the } \\
\text { Estimate }\end{array}$ \\
\hline 1 &, $591^{\mathrm{a}}$ &, 394 &, 330 & 2,222 \\
\hline
\end{tabular}

a. Predictors: (Constant), Inovas (X2), Kreativitas (X1)

Sumber: Hasil Olahan SPSS versi 24 (2020)

Pada tabel 8 diperoleh nilai Adjusted R Square sebesar 0,330 =33\%. Ini berarti variabel independet (kreativitas dan inovasi) secara bersama-sama mempengaruhi variabel dependent (keunggulan bersaing) sebesar 33\% dan sisanya dipengaruhi oleh variabel lain yang tidak termasuk dalam penelitian.

\section{Pembahasan}

\section{Pengaruh Kreativitas Terhadap Keunggulan Bersaing}

Kreativitas merupakan variabel bebas yang diteliti dan diuji. Hasil dari analisis regresi menunjukkan bahwa variabel kreativitas berpengaruh positif dan signifikan terhadap keunggulan bersaing wedding organizer Hastina Puspita Decoration Kota Jambi, dan secara parsial menunjukkan bahwa kreativitas berpengaruh positif dan signifikan terhadap keunggulan bersaing wedding organizer Hastina Puspita Decoration Kota Jambi. Dapat dilihat dari hasil pengujian hipotesis secara parsial yang menunjukkan tingkat signifikansi $0,036<0,05$ dan nilai $t_{\text {hitung }}>t_{\text {ta }}$ 晡el $(2,136>1,667)$ yang artinya variabel kreativitas meningkat, maka keunggulan bersaing akan meningkat. 


\section{Pengaruh Inovasi Terhadap Keunggulan Bersaing}

Inovasi merupakan variabel bebas yang diteliti dan diuji. Hasil dari analisis regresi menunjukkan bahwa variabel inovasi berpengaruh positif dan signifikan terhadap keunggulan bersaing wedding organizer Hastina Puspita Decoration Kota Jambi, dan secara parsial menunjukkan bahwa inovasi berpengaruh positif dan signifikan terhadap keunggulan bersaing wedding organizer Hastina Puspita Decoration Kota Jambi. Dapat dilihat dari hasil pengujian hipotesis secara parsial yang menunjukkan tingkat signifikansi $0,002<0,05$ dan nilai $t_{\text {hitung }}>t_{\text {tabel }}(3,199>1,667)$ yang artinya variabel inovasi meningkat, maka keunggulan bersaing akan meningkat.

\section{Pengaruh Kreativitas dan Inovasi Terhadap Keunggulan Bersaing}

Keunggulan bersaing merupakan variabel terikat yang diteliti dan diuji. Hasil penelitian ini menunjukkan bahwa adanya pengaruh kreativitas dan inovasi terhadap keunggulan bersaing wedding organizer Hastina Puspita Decoration Kota Jambi. Berdasarkan hasil uji $\mathrm{F}$ dengan bantuan perhitungan dari program SPSS 24.0, maka terlihat bahwa nilai $F_{\text {hitung }}$ sebesar 17,959 dan $F_{\text {tabel }}$ sebesar 3,13. Dari nilai ini, maka diperoleh bahwa $F_{\text {hitung }}>F_{\text {tabel }}$ atau 17,959 $>3,13$. Sehingga Ha diterima dan Ho ditolak. Kemudian, jika dilihat dari nilai signifikansinya diperoleh nilai sig. F sebesar 0,000 lebih kecil dari 0,05 atau $0,000<0,05$ sehingga Ha diterima dan Ho ditolak.Sehingga dapat disimpulkan bahwa variabel kreativitas $\left(\mathrm{X}_{1}\right)$ dan inovasi $\left(\mathrm{X}_{2}\right)$ secara bersama-sama berpengaruh terhadap keunggulan bersaing (Y).

\section{SIMPULAN DAN SARAN}

Simpulan

1. Variabel kreativitas $\left(X_{1}\right)$ dan inovasi $\left(X_{2}\right)$ berpengaruh positif dan signifikan terhadap keunggulan bersaing (Y) wedding organizer Hastina Puspita Decoration Kota Jambi secara simultan dan parsial.

2. Variabel inovasi merupakan variabel yang paling dominan mempengaruhi keunggulan bersaing.

3. Hasil analisis Uji Koefisien Determinan $\left(\mathrm{R}^{2}\right)$, secara bersama-sama variabel kreativitas dan inovasi berpengaruh terhadap keunggulan bersaing sebesar $33 \%$ dan sisanya dipengaruhi oleh variabel lain yang tidak termasuk dalam penelitian ini.

\section{Saran}

Berdasarkan hasil penelitian bahwa variabel kreativitas berpengaruh lebih rendah terhadap keunggulan bersaing dibandingkan inovasi, oleh karena itu hendaknya kreativitas lebih dapat ditingkatkan lagi dengan cara menciptakan produk dan desain berbeda dari yang lainnya, menciptakan kombinasi-kombinasi baru untuk mengembangkan usahanya, menciptakan produk dan desain yang bervariatif, selalu bersifat fleksibel dalam mengikuti trend dari waktu ke waktu selain itu juga untuk lebih menciptakan ide-ide kreatif dalam mengkreasikan konsep desain usahanya.

Kepada peneliti selanjutnya yang akan meneliti dengan permasalahan yang sama disarankan agar dapat memilih subjek penelitian dengan karakteristik yang berbedadan menggali variabel-variabel lain yang memiliki pengaruh terhadap keunggulan bersaing dalam berwirausaha. Variabel-variabel lain tersebut seperti kualitas pelayanan, motivasi, harga, brand image dan masih banyak variabel-variabel lainnya. Karena hasil dari penelitian tersebut nantinya dapat memperlengkapi informasi yang akan berguna bagi bidang akademik dan memberikan sumbangan besar bagi ilmu pengetahuan. 


\section{DAFTAR PUSTAKA}

Badan Pusat Statistik. Diakses 25 September 2019, dari : http://bps.gp.id/

Bharadwaj, Sundar G, P.R. Varadrajan, dan Fahly, Jihn (1993). "Suistanable Competitive Advantage in Service Industries: A Conceptual Model and Research Propositions". Journal of Marketing. Vol. 57.

Catherine. (2014). Pengaruh Kreativitas Pengusaha terhadap Keberhasilan Usaha Kecil (Pada Studi Kasus Usaha Dodol di Pasar Bengkel Perbaungan Kab. Serdang Bedagai). Medan : Universitas Sumatra Utara.

Dhewanto, Wawan dkk. (2015). Manajemen Inovasi Untuk Usaha Kecil \& Mikro. Bandung: Alfabeta

Dismawan, R. (2013). Pengaruh Kreativitas Produk dan Inovasi Produk TerhadapKeunggulan Bersaing Produk Kue Soes, (25). Retrieved from http://elib.unikom.ac.id/download.php?id=223229

Fithrati. (2014). Wedding Organizer : Sistem Informasi Wedding Planner Berbasis Web, Volume 3 No 1. AMIK BSI Bandung.

Ghozali, Imam. 2011. Aplikasi Analisis Multivariate Dengan Program IBM SPSS. Badan Penerbit Univeristas Diopnegoro: Semarang.

Graham, Hooley \& Neel, F.Piercy. (2009). Marketing Strategy and Competitive Positioning, edition $4^{\text {th }}$, Pearson.

Hadiyati, Ernani. (2011). Kreativitas dan Inovas Berpengaruh terhadap Kewirausahaan Usaha Kecill. Jurnal Manajemen dan Kewirausahaan. Vol. 13 No. 1. Universitas Gajayana Malang.

Hendro. (2011). Dasar-dasar Kewirausahaan. Erlangga.

Hillls, Gerald. (2008). Maerketing and Entrepreneur-ship, ResearchbIdeas and Opportunities. Journal of Small and Medium Entrepreneur-ship.

Hisrich, D. Robert. (2008). Entrepreneurship Kewirausahaan. Jakarta: Salemba Empat

Husain, Umar. (2002). Metode Penelitian dan Aplikasi dalam Pemasaran. Jakarta : Erlangga.

Kotler, Philip dan Gary, Armstrong. (2004). Dasar-Dasar Pemasaran, Edisi Kesembilan, Jilid 2, Dialih Bahasakan oleh Alexander Sindoro. Jakarta : Indeks.

Kotler, Philip dan Gary, Armstrong. (2005). Manajemen Pemasaran Analisis Perencanaan dan Pengendalian, Jilid Dua. Jakarta : Erlangga.

LAN, (2007). Dimensi Pelayanan Publik dan Tantangannya dalam Administrasi Negara di Indonesia. Jakarta : Bagian Humas dan Punlikasi.

Larsen, P dan Lewis, A (2007). How Award Winning SMEs Manage The Barries to Innovation, Journal Creativity and Innovation Managemen, Page 141- 151.

Ma, Hao. (2004) Toward Global Competitive Advantage : Creation, Competition, Coopration, and Co-option Management Decision. Journal of Management History, Vol. 42 Iss: 7, pp, 907-924.

Maulana, Andri Permadi. (2012). Analisis Pengaruh Kreativitas dan Inovasi terhadap Keunggulan Bersaing Pada Pepeew Indonesia (Studi Kasus pada Bisnis Online Men's Apparel Bandung). Bandung.

Mulyadi, Welly et al. (2016). Pengaruh Inovasi, Kreativitas, dan Kepuasan Konsumen terhadap Keunggulan Kompetitif (Studi Kasus Penggunaan Jasa produk Apple Inc). Universitas Pelita Harapan.

Munandar, S.C. Utami (1999). Kreativitas dan Keberbakatan. Jakarta : Gramedia Pustaka Utama.

Munandar, S.C. Utami. (2009). Pengembangan Kreativitas Anak Berbakat. Jakarta: 
Rineka Cipta

Nawawi, Hadari dan Martini, Hadari. (1992). Instrumen Penelitian Bidang Sosial. Yogyakarta : Gadjah Mada University Press.

Porter, Michael. (1998). Keunggulan Bersaing : Menciptakan dan Mempertahankan Kinerja Unggul. Jakarta : Binarupa Aksara.

Prajogo, D dan Sohal, A. (2003). The Relationship be-tween TQM Practices, Quality Performance, and Innovation Performance. International Journal of Quality and Reliability Management.

Rangga, Disma. (2013). Pengaruh Kreativitas Produk dan Inovasi Produk terhadap Keunggulan Bersaing Produk Kue Soes pada Toko Kue Soes Merdeka di Jalan Merdeka No. 25 Bandung. Jurusan Manajemen Ekonomi. :Universitas Komputer Indonesia.

Rusdi. (2008). Jurnal : Implementasi Teori Kreativitas Graham Wallas Dalam Sekolah Keepenulisan di Pesantren Mahasiswa Hasyim Asy'ari Cabeyan Yogyakarta. Universitas Islam Negeri Sunan Kalijaga Yogyakarta.

Satyagraha, Hadi. (1994). Keunggulan Bersaing dan Aliansi Strategis : Resefinisi SWOT Usahawan, No. 4. Th. XXIII.

Shintia, Derra R. (2012). Pengaruh Inovasi Produk dan Kualitas Produk terhadap Keunggulan Bersaing Pengusaha Batik Trusmi di Kabupaten Cirebon. Fakultas Pendidikan : Universitas Pendidikan Indonesia.

Situmorang, Syafrizal Helmi. 2011. Analisis Data Untuk Riset Manajemen dan Bisnis, Medan: USU Press

Sugiyono. 2005. Memahami Penelitian Kualitatif, Bandung: Alfabeta

Sugiyono. 2012. Metode Penelitian Bisnis. Alfabeta: Bandung

Suharyadi, et al. (2007). Kewirausahaan : Membangun Usaha Sukses Sejak Usia Muda. Jakarta: Salemba Empat.

Supriadi, D. (1994). Kreativitas, Kebudayaan dan Perkembangan IPTEK. Bandung : Alfabeta.

Suryana. (2003). Kewirausahaan, Pedoman Praktis, Kiat dan Proses Menuju Sukses, Edisi Revisi. Jakarta : Salemba Empat.

Triyana, Ugi \& Setiawardani, Maya. (2018). Pengaruh Strategi Inovasi terhadap Keunggulan Bersaing dalam Industri Kreatif Sektor Usaha Minimum Thai Tea di Kota Bandung. Politeknik Negeri Indonesia : Bandung.

Zimmerer, T dan Scarborough, N. (2004). Kewirausahaan dan Manajemen dan Manajemen Usaha Kecil. Jakarta : Salemba Empat.

Zimmerer, Norman \& Wilson, Doug..(2008). Kewirausahaan dan Manajemen U255saha Kecil edisi 5. Jakarta : Penerbit Salemba Empat 